\title{
Effectiveness of Root System of Grasses Used in Soil Conservation in Paundi Khola Sub Watershed of Lamjung District, Nepal
}

\author{
Gandhiv Kafle $e^{1} \&$ Prof. Mohan K. Balla²
}

\begin{abstract}
The study was carried out in Paundi Khola Sub-watershed of Lamjung District, with the objective of evaluating the effectiveness of root system of grasses used in soil conservation. Different root parameters were recorded through direct field measurement. Key informant's survey, semi-structured walk and focus group discussions were also undertaken to acquire relevant information on pattern of retaining grasses, insect/pest condition, local uses of grasses, perceived weeds and perception of farmers on different issues. Stylo and Molasses are most effective in armouring the slope against surface erosion from both runoff and rain splash due to their dense surface cover, low canopy and small leaves. Broom Grass and Napier are most effective in reinforcing the soil by providing a network of strong roots that increases the soil's resistance to shear. Broom Grass can moderately support the soil mass by its strong and long fibrous roots. Broom Grass can bind average $3.8 \mathrm{cu}$. $\mathrm{m}$. soil, and that for napier, stylo, and molasses are $0.37 \mathrm{cu} . \mathrm{m}$., $0.45 \mathrm{cu} . \mathrm{m}$. and $0.04 \mathrm{cu}$. m. soil respectively. It was found that farmers plant the improved varieties of grasses primarily for forage due to high foliage content. Soil conservation is second priority. A combination of improved varieties of grasses and natural grasses helps to conserve soil and moisture more effectively than single-use of grass species on marginal land.
\end{abstract}

Key Words: Effectiveness, Improved grass species, Root, Soil conservation, Napier, Molasses, Stylo, Broom grass.

\section{Introduction}

Soil conservation is an important requirement in sustainable farming. Basics of soil erosion control are to reduce detachment and transportation capacity of the eroding agents (water and wind) through different agronomic, vegetative measures generally known as conservative measures (Amatya and Shrestha, 2002). Good crop husbandry is an effective soil conserving practice (Joshi, 1992). Grasses are generally used to reduce soil erosion. Grasses develop rapidly and produces humus too. They can recover from damage and completer burial.

The improved varieties of grasses have a number of features that make it desirable both from farmers' and projects' point of view. The densely tufted perennial clumps of grass seem not to spread or become a pest and terraces rise as the soil accumulates behind the hedges, converting erodible slopes into stabilized terraces where farming can be carried out safely without threats

\footnotetext{
Wetland Friends of Nepal (WFN), gandhiv@wetlandfriends.org

2 Department of Watershed Management and Environmental Science, Institute Of Forestry, Tribhuvan University, P.

o. Box. 43, Pokhara, Nepal mkballa@iof.edu.np
} 
of erosion. Planting of improved varieties of grasses on the risers will not only bind the soil but also provide a rich source of fodder for the livestock (Pandit, 2002). All the exotic varieties will not be equally effective to favour the soil conservation and cereal crop production in a given locality. The land types and site condition may affect the root and foliage systems of the grasses. Different grasses may have different uses in the locality. Grasses on the risers are important to protect them but they may also affect the crop production. Farmers scrap or slice the natural grasses on the risers every year before the cultivation. The farmers reported that slicing the terrace walls prevents collapse of the riser in the monsoon, adds fertile soil to the terrace below, and minimizes insects, diseases, and rodent problems. But this practice increases soil erosion (Joshi, 1992).

The functions of the root system are engineering (anchorage, armour, catch, reinforcement and drain) and physiological (storage, conduction, and absorption). The fibrous root system of the grasses consists of several main roots that branch to form a dense mass of intermeshed lateral roots. Anchorage is not the main function of shallow rooted species like grass. Armour is the main function and catch, reinforcement and drain (if planted accordingly) are other engineering functions of grasses (Rost et al., 1979)

Site conditions markedly influence the form and pattern of root development. Lateral spread is related to the nature of the rooting medium, being more extreme in sandy soil than in clay (Spur and Barnes, 1980). Plants themselves show considerable variation of rooting depth within the soil profile (Etherington, 1976). A variety of exogenous factors are known to influence the branching pattern of roots (Torrey and Clarkson., 1975).

The maximum effective depth of rooting of plants, and therefore the depth to which they can reinforce or anchor the soil, is also a subject for debate in the world-wide bio-engineering literature. In exceptional cases, it is clear that certain plants can have extremely long roots. Grass clumps can sometimes send roots to four or five metres below the surface and trees can send roots even deeper (Howell, 1999). The rooting habit is the most difficult part of the ecosystem to investigate. Furthermore, the root system is not a static entity but shows continuous extension during the growing season (Etherington, 1976). The majority of roots, especially the small absorbing roots, are located in the upper soil horizons where favourable aeration, nutrients, and moisture conditions occur (Spur and Barnes, 1980).

The rooting depth and lateral spread of roots affect the extent of soil erosion control and competition with the cereal crops for moisture and nutrients. Moreover the foliage system provides the good habitat for insect, pest which will be harmful for the cereals. The present study was carried out to evaluate the effectiveness of root system of four grasses- Napier, Stylo, Molasses and Broom grass used in soil conservation in Paundi Khola Sub-watershed, Lamjung district, Western Nepal.

\section{Study Area}

The study was carried out in the Paundi Khola Sub-Watershed $\left(28^{\circ} 05^{\prime}\right.$ and $28^{\circ} 12^{\prime} 30^{\prime \prime} \mathrm{N}$ latitude and $84^{\circ} 17^{\prime} 30^{\prime \prime}$ and $84^{\circ} 27^{\prime} 30^{\prime \prime}$ E longitude) in Lamjung district, Gandaki zone in the 
Western Development Region. It is $22 \mathrm{~km}$ south-west from Besisahar, headquarter of Lamjung district. It occupies an area of 5877 ha. Its elevation ranges from $500 \mathrm{~m}$ to $2000 \mathrm{~m}$.

The major occupation of majority of people is agriculture. Paddy, maize and millet are the main cereal crops in this sub-watershed. The farming system is traditional that's why the production is very low. Mango, Jackfruit, Nepalese hog plum, Banana and Pears are the main deciduous fruits cultivated by the farmers. Duradanda, Chandresor, Dhuseni and Sundarbazar are the main production areas of citrus fruits e.g. orange, lemon, Sweet or malta orange etc. Only $29.7 \%$ people produce food sufficient for the whole year whereas $21 \%$ people hardly produce food sufficient for less than 3 months from their own. 1.8\% of total 52 House- holds have land less than 5 Ropani. Total livestock number is 15592 with cows 4045, buffaloes 4663, and sheep-goat 6884. Livestock number per HH is 5.7. Most of the livestock are of local breeds.

$69.11 \%$ land area of this sub-watershed is cultivated whereas $30.89 \%$ land area is covered with forest. Sloping terrace covers 2063 ha and level terrace with 1999 ha. The main tree species found are Schima wallichi, Castanopsis indica, Alnus nepalensis, Pine species and Rhododendron species. The farmers have cultivated the improved varieties of the grasses like Napier (Pennisetum purpureum), Molasses (Melinis minutiflora) and Stylo (Stylosanthes guianensis) in the Paundi Khola Sub-Watershed area (Pandit, 2002).

\section{Materials and Methods}

\section{Methodology}

Relevant biophysical and socio-economic information was collected using both primary and secondary sources. Primary data was collected through direct measurement, field observation, questionnaire surveys, semi-structured walk and focus group discussions. During the field observations carried out in October-November 2004, root pattern parameters such as rooting depth, lateral spread of root, local uses of grasses, patterns of retaining grasses and perception of farmers on different issues, were studied and recorded. A reconnaissance field survey was made and then the questionnaires and data entry forms were developed compatible with field condition.

35 clumps of Napier, 17 stands of Stylo, 10 clumps of Broom Grass and 10 Molasses of varying ages were selected by purposive sampling for root pattern measurement. Three groups containing 10-15 farmers adopting improved grass species were formed to conduct group discussion and perceptions as well as other relevant information. A checklist was designed to elicit information on local uses of grasses and insect/pest/rodent condition. Semi-structured interviews were then conducted to collect information which was not obtainable through field observations.

Relevant secondary data and information regarding the study area were collected from the District Soil Conservation Office, Lamjung and Institute of Forestry, Pokhara, Nepal.

Quantitative data was analyzed statistically using Microsoft Excel and Statistical Package for Social Studies (SPSS) software. Wherever possible, this quantitative data were compared 
with corresponding qualitative information. Different geometric and trigonometric principles were applied to analyze the collected data on root pattern of grasses.

\section{Result and Discussion}

\section{Grass species and their local uses}

Improved varieties of grasses were cultivated on $10 \%$ of terrace risers. Improved varieties mainly Napier, Molasses and Stylo were cultivated in terrace risers, edges and marginal land. Farmers practiced the improved varieties of grasses primarily for forage due to high foliage content. Soil conservation was the second priority. Soil is automatically conserved when improved varieties of grasses are cultivated for forage purpose. But only the effective pattern of cultivation of grasses may fulfil the dual purpose-forage production and soil conservation. Napier is reported to increase the amount of milk from buffaloes and meat of goats. Multiple uses of improved varieties of grasses make the farmers to prefer these varieties than local grass species.

\section{Patterns of retaining grasses}

Farmers preferred improved varieties of grasses mainly on the terrace risers, edges and marginal land. The choice of species and pattern of retaining grasses were different on different landuses. Broom Grass was planted mainly on the boundary or edge of the Khet and Bari and the marginal land or pathways. It is because the clump of Broom Grass spreads up to $1 \mathrm{~m}$ in diameter and its foliage exerts shade effect up to $686 \mathrm{~cm}$ maximum distance affecting cereal crops.

\section{Perception of the farmers on terrace riser slicing}

A checklist of issues on terrace riser slicing was prepared and informal small group discussion and semi- structured walk were conducted to obtain the perception of the farmers on terrace riser slicing. The findings are as follows:

1. Terrace riser slicing practice is unavoidable but the quantity (height) of slicing can be minimized.

2. The soil erosion depends upon the height of the riser sliced. The more the slicing height, the more the erosion and vice-versa.

3. Benefit of keeping natural grasses on terrace riser is less than slicing them.

4. Cutting the grass foliage periodically and partial slicing (low height of riser) may be a good technique to keep grasses on terrace riser and edge without inducing soil loss and insect/pest problem.

5. A combination of improved varieties of grasses and natural grasses helps to conserve soil and moisture more effectively than single-use on any land-use.

6. Improved varieties of grasses fulfil the need of forage in dry or off-season. 


\section{Grasses perceived by the farmers as weeds}

Based on direct observation and farmer's experience, Sage Bush (Lantana camara) and Titepati (Artemisia japonica) invaded the growth of Stylo (Stylosanthes guianensis) and Molasses (Melinis minutiflora). No weed was perceived invading in case of Napier (Pennisetum purpureum) and Broom Grass (Thaisanolaena maxima).

\section{Insect/pest condition}

Farmers experienced that the problem of insects/pests is totally ( $>90 \%)$ controlled in improved varieties of grasses but mice are the problems in case of Napier. In Napier, the dense clumps and fibrous roots provide good habitat (hiding place) for mice.

\section{Comparison of effectiveness of grasses by comparative ranking matrix}

A comparative ranking matrix exercise was conducted to assess the effectiveness of four most preferred grasses. Different characteristics of grasses were listed as indicators. Based on the analysis, following conclusions on the preference in descending order are made as follows:

\section{Napier $>$ Broom Grass $>$ Stylo $>$ Molasses}

Easy propagation, fast growth, high forage yield, good palatability, effective restraining of soil particles, quick recovery of roots after damage/complete burial, capacity to establish on diverse environmental conditions and insect/pest free characteristics make Napier (Pennisetum purpureum) superior and preferred species for forage production and soil conservation in the watershed than Stylo, Molasses and Broom Grass.

Broom Grass exerts more shading effects to the adjacent cereal crops. The foliage of Broom Grass falls on the terrace over the cereal crop which restricts the free growth of crops. The practice of retaining Broom Grass on the terrace boundary seems logical to reduce adverse effects to the adjacent crops. So this practice should be promoted.

Farmers' experience show that the palatability of leaves of Broom Grass is low compared to other grasses. Molasses also has good soil binding property at micro level. The root pattern of the Napier and Molasses are more or less similar but the effect of soil conservation of molasses is low than the Napier due to its short roots and less lateral spread. Accordingly, Napier cultivation needs to be promoted in the area Stylo is mostly preferred for forage production. It has no shading effect, that's why it should be promoted in the terrace risers and edges.

\section{Root pattern of grasses}

The rooting depth and root lateral spread of four grasses are presented in the table 1 below: 
Table 1: Root Pattern of Grasses

\begin{tabular}{|c|l|c|c|c|c|}
\hline S.N. & \multirow{2}{*}{ Grasses } & \multicolumn{2}{|c|}{ Rooting depth } & \multicolumn{2}{c|}{ Root lateral spread (radial from the clump) } \\
\cline { 3 - 6 } & & Range & Mean & Range & Mean \\
\hline 1. & Napier & 14 to $54 \mathrm{~cm}$ & $39.7 \mathrm{~cm}$ & 19 to $73 \mathrm{~cm}$ & $53.5 \mathrm{~cm}$ \\
\hline 2. & Stylo & 24 to $103 \mathrm{~cm}$ & $79 \mathrm{~cm}$ & 25 to $115 \mathrm{~cm}$ & $90.3 \mathrm{~cm}$ \\
\hline 3. & Molasses & 15 to $27 \mathrm{~cm}$ & $11.8 \mathrm{~cm}$ & 11 to $30 \mathrm{~cm}$ & $18.7 \mathrm{~cm}$ \\
4. & Broom Grass & 70 to $95 \mathrm{~cm}$ & $25.4 \mathrm{~cm}$ & 103 to $132 \mathrm{~cm}$ & $28.9 \mathrm{~cm}$ \\
\hline
\end{tabular}

\section{Effectiveness of engineering functions of grasses}

Engineering functions of grasses can be categorized into 6 categories: catch, armour, reinforce, anchor, support and drain (Howell, 1999). Anchorage and support are not the main functions of shallow rooted grasses. Armour is the main function of shallow rooted species. Catch, reinforce and drain are secondary functions if planted accordingly. However, the relative importance of four grasses has been evaluated on the basis of parameters (root pattern and foliage pattern) directly measured in the field. The effectiveness of engineering functions of four grasses is compared in Table 2 below.

Table 2: Comparison of Engineering Functions of Grasses

\begin{tabular}{|c|c|c|c|c|c|}
\hline \multirow[t]{2}{*}{$\begin{array}{c}\text { Eng. } \\
\text { Functions }\end{array}$} & \multicolumn{4}{|c|}{$\begin{array}{c}\text { Grasses and } \\
\text { Their Importance }\end{array}$} & \multirow{2}{*}{\begin{tabular}{|l|}
\multicolumn{1}{|c|}{ Justification (Criteria) } \\
$\begin{array}{l}\text { The following criteria are } \\
\text { used to assess importance } \\
\text { of grasses. }\end{array}$ \\
\end{tabular}} \\
\hline & Napier & Stylo & Molasses & $\begin{array}{l}\text { Broom } \\
\text { Grass }\end{array}$ & \\
\hline Catch & $\begin{array}{l}\text { Very } \\
\text { Good }\end{array}$ & $\begin{array}{l}\text { Moderately } \\
\text { useful }\end{array}$ & $\begin{array}{l}\text { Moderately } \\
\text { useful }\end{array}$ & Excellent & $\begin{array}{l}\text { Strength, numbers and } \\
\text { flexibility of stems. Ability } \\
\text { to recover from damage }\end{array}$ \\
\hline Armour & Good & Excellent & Very good & $\begin{array}{l}\text { Moderately } \\
\text { useful }\end{array}$ & $\begin{array}{l}\text { Extent of surface cover of } \\
\text { wegetation. Conopy height } \\
\text { Size of leaves. }\end{array}$ \\
\hline Reinforce & $\begin{array}{l}\text { Very } \\
\text { good }\end{array}$ & $\begin{array}{l}\text { Moderately } \\
\text { useful }\end{array}$ & $\begin{array}{l}\text { Moderately } \\
\text { useful }\end{array}$ & Excellent & $\begin{array}{l}\text { Strength ond number of } \\
\text { fbrous roots }\end{array}$ \\
\hline Anchor & - & - & - & - & Depth of rooting \\
\hline Support & - & - & - & $\begin{array}{l}\text { Moderately } \\
\text { usefill }\end{array}$ & Depth of rooting \\
\hline
\end{tabular}

\section{Effectiveness of hydrological functions of grasses}

The hydrological functions of grasses vary each other due to variation in their root pattern, foliage pattern and pattern of retaining them in the watershed. To achieve effective hydrological functions, the grasses should be cultivated in mix, not monoculture. The effectiveness of hydrological functions of four grasses is compared in Table 3 below. 
Table 3: Comparison of Hydrological Functions of Grasses

\begin{tabular}{|c|c|c|c|c|c|}
\hline Grasses & \multicolumn{4}{|c|}{ Hydrological functions } & Justification \\
\hline & Interception & Storage & $\begin{array}{l}\text { Leaf } \\
\text { drib }\end{array}$ & Infiltration & \\
\hline Napier & Very good & $\begin{array}{l}\text { Very } \\
\text { good }\end{array}$ & $\begin{array}{l}\text { Very } \\
\text { good }\end{array}$ & Excellent & $\begin{array}{l}\text { Fibrous roots up to } 54 \mathrm{~cm} \text { deep, } \\
\text { height up to } 4.35 \mathrm{~m} \text {, FLS up to } \\
2 \mathrm{~m} \text {, non-woody stem, clumping }\end{array}$ \\
\hline Stylo & Moderate & Moderate & Good & Moderate & $\begin{array}{l}\text { Tap root up to } 1 \mathrm{~m} \text { deep, FLS up } \\
\text { to } 1.9 \text { m, non woody stem, small } \\
\text { leaves, creeping foliage, less } \\
\text { root branching }\end{array}$ \\
\hline Molasses & Moderate & Moderate & Moderate & Very good & $\begin{array}{l}\text { Fibrous roots up to } 27 \mathrm{~cm} \text { deep, } \\
\text { up to } 1 \mathrm{mFLS} \text {, up to } 1.2 \mathrm{~m} \\
\text { height }\end{array}$ \\
\hline $\begin{array}{l}\text { Broom } \\
\text { Grass }\end{array}$ & Excellent & Excellent & Excellent & Moderate & $\begin{array}{l}\text { Up to } 4.9 \mathrm{~m} \text { tall, up to } 5.14 \mathrm{~m} \\
\text { FLS, strong Fibrous roots up to } \\
95 \mathrm{~cm} \text { deep, non-woody stem, } \\
\text { clumping }\end{array}$ \\
\hline
\end{tabular}

\section{Effectiveness of soil binding capacity of roots of different grasses}

Broom Grass is excellent in soil binding capacity whereas Stylo is very good, Napier good and Molasses moderate.

Details of soil binding function of four grasses are presented in Table 4 below.

Table 4: Comparison of Soil Binding Capacity of Roots of Grasses

\begin{tabular}{|l|l|l|}
\hline \multicolumn{1}{|c|}{ Grasses } & Soil binding function & \multicolumn{1}{|c|}{ Justification(Volume of soil bound by roots) } \\
Napier & Good & $0.37 \mathrm{cu} \cdot \mathrm{m}$, fibrous roots \\
\hline Stylo & Very good & $0.44 \mathrm{cu} \cdot \mathrm{m}$ tap roots \\
\hline Molasses & Moderate & $0.037 \mathrm{cu} . \mathrm{m}$ fibrous roots \\
\hline Broom Grass & Excellent & $3.778 \mathrm{cu} . \mathrm{m}$ fibrous roots \\
\hline
\end{tabular}

\section{Effectiveness of forage production of grasses}

The height and lateral spread of foliage determines the quantity of forage production in vegetation. Actual biomass is not obtained but relative productivity of foliage can be estimated by height and foliage lateral spread. Tall grasses with more foliage lateral spread produces more forage for livestock.

Accordingly, the findings are presented in the table 5 below: 
Table 5: Comparison of Forage Production of Grasses

\begin{tabular}{|l|l|l|}
\hline \multicolumn{1}{|c|}{ Grasses } & \multicolumn{1}{|c|}{$\begin{array}{c}\text { Forage } \\
\text { production } \\
\text { fumction }\end{array}$} & \multicolumn{1}{|c|}{ Justification } \\
\hline Napier & Excellent & $\begin{array}{l}\text { Height upto } 4.35 \mathrm{~m} \text {, FLS upto 2m, non-woody stem, } \\
\text { clumping }\end{array}$ \\
\hline Stylo & Very good & $\begin{array}{l}\text { FLS upto } 1.9 \mathrm{~m} \text {,non woody stem, small leaves, creeping } \\
\text { foliage, }\end{array}$ \\
\hline Molasses & Good & upto $1 \mathrm{~m}$ FLS, upto $1.2 \mathrm{~m}$ height \\
\hline $\begin{array}{l}\text { Broom } \\
\text { Grass }\end{array}$ & Moderately good & $\begin{array}{l}\text { Upto } 4.9 \mathrm{~m} \text { tall, upto } 5.14 \mathrm{~m} \text { FLS, non-woody stem, } \\
\text { clumping } \\
\text { But palatability less }\end{array}$ \\
\hline
\end{tabular}

\section{Conclusion}

Improved varieties of grasses fulfil the need of forage in dry and/or off-season. Farmers plant the improved varieties of grasses primarily for forage due to high foliage content. Soil conservation is secondary priority. Soil seems automatically conserved when improved grass species are cultivated for forage production purpose. So, cultivation of improved grass species mainly Napier (Pennisetum purpureum), Molasses (Melinis minutiflora) and Broom Grass (Thaisanolaena maxima) must be promoted on various land uses.

Farmers believe that cutting the grass foliage periodically and partial slicing (low height of riser) may be good technique to keep grasses on terrace risers and edges without inducing soil loss and insect pest problem. But it has not been practiced yet in the study area because farmers do not want to take risk of insect pest problem. So trial plots should be established in the study area and the practice of cutting the grass foliage periodically and partial slicing of terrace risers should be evaluated. Moreover, further research should be conducted to assess the economics of grass growing on terrace risers.

Farmers have a nice experience of cultivating improved varieties of grasses such as Napier (Pennisetum purpureum), Stylo (Stylosanthes guianensis) and Molasses (Melinis minutiflora) together with natural grasses in marginal land, stream bank, and open ground. It seems more effective to conserve soil and moisture than any monocultures or natural grasses alone, or improved grasses alone. Therefore, it can be concluded that a combination of improved varieties of grasses and natural grasses helps to conserve soil and moisture more effectively than singleuse of grass species on marginal land. This practice should be promoted. For this, planting materials such as the seeds/seedlings/cuttings etc should be provided and trainings on cultivation aspects of the improved grass species should be conducted at local level.

Stylo and Molasses are most effective in armouring the slope against surface erosion from both runoff and rain splash due to their dense surface cover, low canopy and small leaves. Broom Grass and Napier are the most effective in reinforcing the soil by providing a network of strong roots that increases the soil's resistance to shear. Broom Grass can moderately support the soil mass by its strong and long fibrous roots. But it should be noted that shallow-rooted grasses can provide functions of anchoring and supporting at micro scale. Clumping, good 
fibrous roots and up to $2 \mathrm{~m}$ foliage lateral spread proves Napier (Pennisetum purpureum) most effective in infiltration of rainwater. Raindrops are intercepted by its long leaves that flow down through stem. Fibrous root system of napier, molasses and Broom Grass has ability to bind the soil in cylindrical pattern below the ground. Root lateral spread exceeds the rooting depth. But in case of tap-rooted Stylo, root pattern is of conical type. Broom Grass is excellent for soil binding ( $3.778 \mathrm{cu}$. m. soil volume) due to its strong fibrous roots. Long tap roots and conical pattern enable stylo to bind soil more than Napier. But when Napier attains large clumping after certain period, it can bind more soil than the Stylo because Stylo can not attain clumping. Mat formation is excellent in Napier and Molasses due to their fine fibrous roots spreading few centimetres below the ground surface. Napier is excellent in forage production function and its palatability is also high (based on farmers' experience). Broom Grass produces more foliage but its palatability is less. Stylo and molasses are cultivated together and their forage productivity is satisfactory.

\section{Acknowledgement}

The authors are thankful to NARMSAP/DANIDA, Western Regional Office Pokhara for financial support. The paper is based on research project submitted by the first author to Institute of Forestry, Pokhara, Nepal for the partial fulfilment of Bachelor Level of Science, 2005.

\section{References:}

Amatya, S. M., and Shrestha, K. L.,(2002). Nepal Forestry Handbook. FAO, Italy, Rome.

Joshi, R. B., (1992). Indigenous Practices of Soil and Water Conservation in Farmlands. A Case Study of Bishnu Village Development Committee, Kathmandu, Nepal.

Pandit, K., (2002). An Evaluation of Terrace Improvement Techniques in Paundikhola Watershed of Lamjung District Nepal. A thesis submitted to Institute of Forestry Pokhara for the partial fulfillment of the bachelor degree in forestry. pp 24-31.

Rost, T. L., Barbour M.G., Thornton, R. M., Weier, T. E., and Stocking, C. R., (1979). Botany: A Brief Introduction to Plant Biology. John Wiley and Sons. Inc, pp 84-94.

Spur, S. H., and Barnes, B. V., (1980). Forest Ecology, $3^{\text {rd }}$ Edition. John Wiley and Sons, Inc. London. pp 87-93.

Etherington, J. R. (1976). Environment and Plant Ecology. Wiley Eastern Limited, New Delhi.

Torrey, J. G., and Clarkson, D. J., (1975). The Development and Function of Roots: Third Cabot Symposium. Academic Press, London, New York, San Francisco.

Howell, J., (1999). Roadside Bioengineering: Reference manual. Department of Roads. His Majesty's Government of Nepal, Kathmandu, Nepal. 